\title{
THE SYMBOLISM OF 'ECO CARS' ACROSS NATIONAL CULTURES: POTENTIAL IMPLICATIONS FOR POLICY FORMULATION AND TRANSFER
}

David P Ashmore ${ }^{a *}$, d.ashmore.12@ucl.ac.uk, ORCID: 0000-0002-1649-1962.

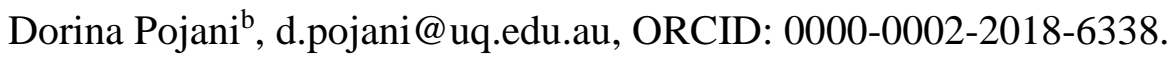

Roselle Thoreauc ${ }^{\mathrm{c}}$, r.thoreau@ auckland.ac.nz, ORCID: 0000-0003-1809-428X.

Nicola Christie ${ }^{\mathrm{a}}$, nicola.christie@ucl.ac.uk, ORCID: 0000-0001-7152-5240.

Nicholas A Tylera, n.tyler@ucl.ac.uk, ORCID: 0000-0001-7079-1301.

a Centre for Transport Studies, Department of Civil Environmental and Geomatic Engineering, University College London, Gower Street, London WC1E 6BT, United Kingdom

$\mathrm{b}$ The University of Queensland, School of Earth and Environmental Sciences, Faculty of Science, St Lucia, Brisbane, Queensland 4072, Australia.

${ }^{c}$ The University of Auckland, Faculty of Engineering, 20 Symonds Street, Auckland 1010, New Zealand.

*Corresponding author: d.ashmore.12@ucl.ac.uk, dave_ashmore@yahoo.co.uk, +44 (0)20 76797224

\begin{abstract}
Transport choices are not merely practical decisions but steeped in cultural and societal perceptions. Understanding these latent drivers of behaviour will allow countries to develop and import policies to more successfully promote sustainable transport. Transport symbolism - what people believe their ownership or use of a mode connotes to others about their societal position - has been shown to be one such, non-trivial, hidden motivator. In the case of hybrid and electric cars ('eco cars'), studies have demonstrated how their symbolic value varies within a society among different social groups. As yet, however, there has been scant research into comparing how the symbolism of a mode varies across national cultures, horizontally, between individuals
\end{abstract}


with similar socio-demographic characteristics. Through qualitative thematic analysis, this study utilises two of Hofstede's cross-cultural indices - power differential and individualism versus collectivism - to develop and strengthen theory on how the differing symbolism of eco cars currently varies between four cultural clusters - Anglo, Nordic, Confucian and South Asian. It also deliberates how observed symbolic qualitative differences may influence an individual or group choice to procure eco cars. Finally, it discusses how policy development, transfer and marketing, within the context of eco cars, may need to be modified by national governments, in the Confucian and South Asian cultures, so as to encourage uptake and modal shift.

Keywords: symbolism; hybrid cars; electric cars; national culture; latent motivation; policy transfer.

Declarations of interest: none.

\section{Funding bodies}

This research did not receive any specific grant from funding agencies in the public, commercial, or not-for-profit sectors.

9,100 words excluding appendices and bibliography. 


\section{$1 \quad$ Introduction}

Two latent drivers of behavior are symbolism and national culture. Symbolism explains how people use objects and signs to signify something about themselves to third parties within the context of a society (Saussure et al., 1916). Culture can be defined as the 'set of attitudes, values, beliefs and behaviours shared by a group of people' (Matsumoto and Juang, 2012). National culture, a subset of culture, increasingly explored over recent decades, has been defined by Hofstede (1984) as 'the collective programming of the mind that distinguishes the members of one national group from another'.

When examining the hidden factors underpinning people's transport choices, both symbolism and national culture have been shown to be important (Steg, 2005; Syam, 2014). This has ramifications for transport policy transfer. For example, much of the world's future vehicle emissions are predicted to take place in developing ${ }^{1}$ countries where car ownership is rapidly rising (Zhou et al., 2010; Siddique et al., 2011; Dargay et al., 2007). Yet, in seeking to promote sustainable transport, if the government of developing country $\mathrm{X}$ attempts to import a remedial policy solution from developed country $\mathrm{Y}$, the effectiveness of the proposed solution may be compromised if the policy possesses poor or no symbolic value within the new culture. In such instances tailored policies and marketing programmes may be necessary to raise the symbolic value of a mode to encourage modal shift.

The symbolic value of eco cars has already been explored in developed nations and shown to be significant among certain social groups (Heffner, 2007). Little research has, however, been undertaken on the symbolism of eco cars in developing countries. This paper sets out to

\footnotetext{
1 Throughout this article the term 'developing countries' will be used to denote 'industrialising', 'emergent' and 'low and middle income' nations, and 'the Global South'. Deliberation of the appropriateness of the term is outside the scope of this article. For a comprehensive discussion see World Bank (2015).
} 
address this absence, through qualitative analysis, to facilitate an expansion of theory for later quantitative testing among the populations of interest. Given the research straddles different epistemologies it also aims to help bridge gaps between traditional transport planning and the emerging field of mobilities (Wind et al., 2012).

The first part of this paper lays out the theoretical background. It outlines symbolism and national culture in more detail and poses the question as to how they may affect policy transfer between nations. Work carried out to date on the symbolism of eco cars in Europe and North America is then presented, before positing theory, drawing on the Hofstede (1984) indices, as to how this may differ in Confucian and South Asian cultures, such as China and India. The study method, qualitative deductive thematic analysis, is then outlined, stressing its compatibility with the goal of the expansion of theory. The penultimate section describes observed thematic differences in the symbolism of eco cars between interviewees of similar socio-demographic backgrounds, across four different national cultural clusters as defined by Hofstede (1984) - Anglo, Nordic, Confucian and South Asian. The paper concludes by placing the findings within the context of transport policy formulation, transfer and implementation.

\section{Theoretical background}

\subsection{Symbolism}

Symbolism has been shown to be a latent driver of travel behaviour (Steg, 2005). In economically stratified societies the symbols that people display, serve as objective criteria to compare oneself to others (Lindemann, 2007; Festinger, 1954). To give an example, a person wearing a luxury branded watch may be demonstrating affluence, a place in the social 'pecking order', a tacit instruction to others as to how they should be treated. The manner in which groups and individuals use symbols to self-define and relate to others in society falls 
within the field of symbolic interactionism, a discipline predicated on the belief that humans socially interact with their fellows through the meaning of things (Blumer, 1986).

The role of symbols in social communication was first theorised by linguists and semioticians. Saussure et al. (1916) postulated that a sign, or symbol, has two meanings: a signifier or objective meaning, and a signified - what the sign may communicate to others about the displayer. Hjelmslev (1953) and Barthes $(1957,1967)$ took the concept of the signified a stage further by suggesting that a symbol has two implications, a denotation and a connotation, the connotation being a deeper meaning of that which is shown at the surface level. Barthes (1967) argued that it is the connotations of a symbol that drive behaviour.

The concept of symbolism in transport is widely theorised, most strongly around the meaning of the private car. Belk (1988) describes how for many young American males, the automobile is a symbol of masculinity, part of the owner's extended self and ego. Miller (2001) summarises how in the literature the car is depicted as a symbol of modernity. Pojani and Stead (2015a) state that at a collective societal level, private cars have long connoted comfort, speed, pleasure, power, protection, individuality, and superiority. Gartman (2004) believes that early automobiles conferred cultural capital on the high bourgeoisie in American society by attesting to their owners' removal from the necessity of work. Choo and Mokhtarian (2004) identified that some people bought specific makes and models of cars because they believed that their car symbolised strong aspects of their personality to others.

Symbolism as an explicit, latent variable in transport choice, was quantitatively derived only relatively recently by Steg (2005). She did not merely allude to symbolism but utilised a theoretical model of motivation - devised by Dittmar (1992) - to isolate symbolism as a proxy variable through factor analysis. This allowed it to be clearly distinguished from two other aspects of choice motivation: instrumental (practical, measureable), and affective (how a person feels emotively, arousal). 


\section{$2.2 \quad$ National culture}

There are many conceptualisations of culture. In 1952 over 164 definitions were identified by Kroeber and Kluckhohn (1952). Hofstede (1984) defines culture as the collective programming of the mind which distinguishes the members of one group or category of people from another. The manifestation of culture can vary either vertically, by income or wealth (e.g. working class culture), or horizontally, across a uniform social group (e.g. car culture). While culture has long been important in fields such as anthropology and sociology, it would appear to be the advent of the study of mobilities that has led to it becoming increasingly discussed in the transport literature. For example, one of the four critical aspects of urban mobility as described by Kuhnimhof and Wulfhorst (2013) is 'perceptions and lifestyle orientation', a construct heavily influenced by cultural background. Kuhnimhof and Wulfhorst (ibid) see perceptions and lifestyle orientations as being influenced by the cultural background of the decision maker, as well as their socio-economic categorisation, status concerns, and social norms; these in turn exert an influence on travel options and how they are perceived.

One particular aspect of culture which has received significant attention in recent decades, largely due to globalisation, is national culture (Markus and Kitayama, 1991; Steenkamp, 2001; Strohschneider, 2002; Swaidan, 2012). A country's culture has long been identified as a key characteristic underlying systematic differences in behaviour at a general level (Malhotra and McCort, 2001). Koçak et al. (2007) opine that it leads to different national populations making varying choice evaluations. Sasaki and Yoshikawa (2014) see national culture as dynamic, ever changing. In the broader transport literature there are a handful of references on national culture's influence on choice and perception (Tansey et al., 1990; Lee et al., 2015; Oliver and Lee, 2010; Kim and Lee, 2009; Takahashi, 2010; Syam, 2014; Syam et al., 2011; Law and Karnilowicz, 2015). 
When undertaking cross cultural comparisons, sampling is crucial, not only determining which nations to sample, but which groups to sample within each nation (Buil et al., 2012). When segmenting nations, the most commonly used cross cultural indices are those of Hofstede (1984). Over three quarters of all cross-cultural studies draw upon them across several disciplines (Ng et al., 2007; Williamson, 2002; Jones, 2007). Magnusson et al. (2008) compared different cultural frameworks and concluded the ever evolving and more recent cultural frameworks provide only limited advancements over Hofstede's model, which has been used in many more studies. In using the Hofstede indices no allegations of superior explanatory power are made, only that they are a solid basis for initial segmentation.

Furthermore the authors wish to acknowledge the contentious nature of cross-cultural studies, something which seeks to generalise about the collective at the expense of the individual, in an evolving world. It has been argued that modernism and global media are set to render national culture obsolete - Taras et al. (2012) argue that consumerism within the developing world is leading to cultural convergence. Many strongly disagree with these sentiments. Witchalls (2012) sees the homogenisation of national culture as being impossible: when processing new information from outside, cultures make reference to their existing values and norms to self-reinforce. Furthermore in discussing the potential obsolescence of indices such as Hofstede's (1984), Minkov and Hofstede (2011) note that the scores measure relative not absolute difference, and as all modern societies are broadly evolving in the same direction, relative difference will continue to be maintained; Inglehart and Baker (2000) stress the persistence of national culture in the face of globalisation.

Two of the Hofstede indices were used in this research - the power differential (PDI), and the collectivism/individualism index (COLL/IND). The two indices are correlated: collective societies tend to have high power differential indices. These indicators also act as a proxy for developed (low PDI/individualistic) and developing (high PDI/collectivist) countries. 
Furthermore, both reflect the consensus among cultural theorists that some societies place a greater stress on hierarchy and the importance of the group needs over those of individuals.

People in societies with a high degree of PDI accept a vertical stratification in which everybody has a place that needs no justification; people emphasise their position through symbols and behaviour, so others know how to treat them. The COLL/IND index describes the extent to which individuals are willing to subvert their own desires to that of the collective in exchange for loyalty. In collectivist societies decisions are usually made as a group so as to maintain the group's social position and outward dignity. For this reason, in high PDI/collectivist nations, it is common for the collective unit to seek conformative social proof (normative cues) from advertising, peers, and groups they aspire to become members of (Burnkrant and Cousineau, 1975). This is much less the case in individualistic societies (Zhang and Neelankavil, 1997). Moreover, in high PDI societies people do what is socially correct, are less free to do things in their own way, than in low PDI societies where people are freer to make decisions based on individual criteria (Hofstede 1984).

\subsection{Policy transfer}

Barthes's (1957) view that symbols signify varying things in different cultures offers strong implications for transport policy transfer. Although policy makers have always engaged in comparative learning and transfer, the phenomenon of policy mobility (Baker and Temenos, 2015) has become much more widespread in recent decades due to increased global competition, the internet, and global media (González, 2011; Pojani and Stead, 2015b; Marsden and Stead, 2011; Wang, 2010). Planning ideas and practices are not just diffusing from the 'West to the rest', but in every direction (Healey, 2010).

The search for new policies which may be seen as missing or dissatisfactory in one place, and the process of policy transfer from elsewhere, are often closely connected to the notion of 
'best practice', and the idea that 'successful' initiatives can be replicated to equal effect in other settings. Studies, however, have observed distortions and irrational or unpredicted outcomes when policies are transferred, both in the way best practice information is 'sent' and 'received'. Both Pojani and Stead (2015b) and Daniell (2014) cite cultural orientations or biases as a potential reason for this. As the bulk of future motorisation and transport externalities are likely to be concentrated in cities of the developing world (Stead and Pojani, 2017; Dargay et al., 2007; Harris, 2006) wantonly importing solutions from developed countries may not therefore be optimal. To achieve the greatest impact it may be necessary to tailor policies to suit the cultural norms of a recipient nation.

\subsection{The symbolism of eco cars}

Both hybrid and electric vehicles are designed to reduce vehicle emissions and pollutants at the point of usage, so can be seen as one of the policy options within the sustainable transport 'suite'. Hybrid vehicles are partly powered through braking energy being captured in a battery; when battery levels are insufficient, reversion is possible to regular gasoline based propulsion. Electric or 'plug-in' vehicles operate purely on electricity stored in batteries recharged overnight or at charging stations during the day.

It is as yet unclear as to whether or not hybrid or electric vehicles yield a payback over conventional petrol vehicles over a set time period. In the case of hybrids the calculation depends not only on the purchase price of the cars, but also the cost of battery replacement, exemptions from charges and levies, local fuel prices, and the frequency of regenerative braking (Choi and Oh, 2010; Chua et al., 2010; Heffner et al., 2007; Lave and Maclean, 2001). Electric vehicles also have significant limitations compared to their internal combustion counterparts, including being more expensive, possessing lower range, requiring 
longer refuelling times, and having less publically accessible refuelling opportunities (Mersky et al., 2016).

Therefore, to encourage people to migrate to these newer technologies, governments across the world have put in place purchasing and usage incentives. These include capital grants, tax breaks, and user charge exemptions (Diamond, 2009; Yabe et al., 2012; Helveston et al., 2015; Sierzchula et al., 2014; Langbroek et al., 2016; Silvia and Krause, 2016; Ajanovic and Haas, 2016; Lévay et al., 2017). Yet an individual's decision to procure hybrid and electric cars, on the surface, still remains fiscally irrational (Turrentine and Kurani, 2007). Whilst practically the decision may appear illogical, however, emotionally it does not, and latent drivers of behaviour appear to be playing a key role. For example, Langbroek et al. (2016) describe how in Stockholm, people who believe they can affect changes in environmental outcomes through their own actions, are more inclined to purchase electric vehicles.

Symbolism also acts as a motivator. For some people, the image and social prestige gained from driving a hybrid vehicle seem to be the most important determinants in purchasing choices (Chua et al., 2010; Anable et al., 2011). Heffner et al., (2007), within the context of the culture of the United States, describe five denotations (surface symbolism) of owning a hybrid car: preserving the environment; opposing war over oil; managing personal finances; reducing support to oil producers; and embracing new technology. Each of these denotations brings several connotations including: personal ethics, concern for others, community orientation, intelligence, maturity, personal independence, national independence, individuality, and support for local manufacturers. Heffner et al., (2007) argue it is these symbolic connotations, being 'seen to be green' (Berth, 2011) that truly motivate a decision to purchase a hybrid car.

In their drive to tackle air pollution both the Chinese and Indian governments are encouraging people to purchase eco vehicles. In 2009 the Chinese government launched a subsidy scheme 
for this purpose (Hao et al., 2014). The New York Times (2017) flagged how these incentives led to greater percentages of electric vehicles being sold, albeit from a very low base. In India the energy minister stated in 2017 that 'by 2030 not a single petrol or diesel car should be sold in the country, only electric vehicles' (PTI, 2017). In each country production capabilities have been up-scaled with incentives offered to local manufacturers (Clifford, 2016; Indian Express, 2014).

Very little work, however, has been undertaken on the symbolism of eco cars in the urban areas of Confucian cultures such as China, and South Asian cultures such as India. The only exception that the authors found was work by Helveston et al., (2015) who contrasted the motivation for purchasing electric vehicles in China and the USA. The results of their analysis suggested that, whilst in the USA ownership of an eco car may confer social status, this was not the case in China. This paper seeks to explore and expand this finding, by examining how negative, or an absence of symbolism entirely, may be explained by cultural imperatives, and what the implications for eco car uptake and policy transfer might be.

\section{$3 \quad$ Method}

\subsection{Thematic analysis}

A full description of method is offered in (Ashmore et al., In Press). Qualitative analysis was the chosen method in this study as its techniques are extremely useful when examining symbolic motivation (Coolican, 2009; Bryman, 2012) and national cultural differences (Karasz and Singelis, 2009). This is because symbolic motivation is something people often prefer not to acknowledge, downplay, or become evasive about for reasons of embarrassment (Noppers et al., 2014; Heffner et al., 2007; Zaltman and Coulter, 1995; Rapaille, 2001; Ni, 2008; Steg et al., 2001). 
The analytical process needed to illuminate the extent to which symbolic barriers within a culture may hinder the transfer of sustainable transport policies from another. It also had to lend itself to further developing these insights into attitudinal or choice-based quantitative survey instruments to be tested on a target population at a later stage. Thematic analysis was therefore chosen, as it fulfils these objectives by acting as a flexible 'bridge between differing research fields' (Denzin and Lincoln, 2005; Miller and Crabtree, 1992). According to Boyatzis (1998) through thematic analysis, positivistic and interpretative science can communicate to allow ideas to be converted to survey instruments for testing. Another advantage of thematic analysis is that an innovative hypothesis or theory can spring from a single bold comment (Vaismoradi et al., 2013).

Thematic analysis works by allocating 'codes', blocks of interview texts, to a 'theme' (Braun and Clarke, 2006). The incidence of coding density per group for each theme is a useful indicator of the strength of difference between groups, as well as the extendibility of a theory to overall populations. Themes can be derived deductively, post engagement with theory, or inductively, emerging from the data (Boyatzis, 1998; Fereday and Muir-Cochrane, 2008; Braun and Clarke, 2006). The choice of deductive or inductive analysis is not an arbitrary decision, but depends upon the degree to which theory has already been engaged. In this work considerable cross-cultural theory had been studied prior to the derivation of themes, deductive analysis was therefore used. Whilst formal inductive analysis has not been undertaken, the interpretations offered later in the paper, can be seen as a first tentative step to more formal inductive work.

\subsection{Development of deductive themes}

The themes to be explored derive directly from the Hofstede (1984) power differential (PDI) and collectivism versus individualism (COLL/IND) indices, described earlier. The use of 
these particular Hofstede indices does not imply that the others - masculine/feminine and uncertainty avoidance - lack explanatory power in this context, only that the PDI and COLL/IND indices offer the strongest contrast in scores between the groups to be contrasted.

Making reference to the PDI index, Hofstede et al. (2010) state that:

Visible signs of status in large power distance countries contribute to the authority of bosses. A subordinate may feel proud his boss drives a bigger car than his neighbour's boss...[whereas] in small power distance situations status symbols are suspect... subordinates will likely comment negatively to neighbours if their boss spends company money on an expensive car.

Following this line of reasoning, Ashmore et al. (2017) surmise that in high PDI/collectivist cultures, such as India and China, there may be a symbolic imperative for the transport mode owned and used to clearly represent the user's and their family's status, through a clear demonstration of economic and purchasing capacity. Based on this assumption, one could also surmise that major transport decisions will be made collectively by the extended family group, using normative cues, so as not to place the group's social position in jeopardy by 'standing out' (Shavitt et al., 2010; Savani et al., 2012). The authors further speculate that these dynamics are either absent, or if present, then observable to a much lesser degree, in low PDI/individualistic nations such as the United Kingdom and Norway.

One further consideration in low PDI/individualistic nations, is the degree to which migrants from high PDI/collectivist nations may have retained the symbolic values of their home nation. Some migrant groups may have remained largely insulated from the recipient nation's culture, or have tried to preserve the cultural values of their country of origin to pass them down to subsequent generations. Others may be only recently arrived and are yet to fully understand the cultural values of their new nation. For example, Syam (2014) found 
that in New Zealand, migrants with cultural backgrounds rooted in high power differential societies feel that owning and driving a car affords them higher social status ${ }^{2}$. This sentiment was present to a much lesser degree in equivalent social groups whose cultural background was embedded in New Zealand's predominant low power differential 'Anglo' culture.

Focusing on eco cars, this line of inquiry lends itself to three derived themes:

1. Eco cars possessing positive symbolism within a culture.

2. Eco cars possessing neutral or no symbolism within a culture

3. Eco cars possessing negative symbolism within a culture.

These three themes are expanded upon in Appendix A which offers a generic modal symbolism codebook, i.e. not purely pertaining to eco cars, but capable of being used without adaptation when examining other modes. Broadly speaking, the authors hypothesised that for the high PDI/collectivist interviewees, there would only be positive symbolism attached to eco cars if the purchase price was widely known to be higher than equivalent petrol models. Drawing on findings expressed by commentators such as Chatterjee (2008) and Harris (2006), who describe a lack of environmental awareness in India and China respectively, it was also expected that the high PDI/collectivist interviewees would state that in their culture little symbolic credibility could be gained through an outward show of concern for the environment.

In contrast, however, drawing upon sources such as Heffner et al. (2007), the authors expected that, for the interviewees from the low PDI/individualistic cultures, eco cars would possess positive symbolism by denoting environment awareness, and connoting education. The authors, however, expected that among the low PDI/individualistic interviewees, some

\footnotetext{
${ }^{2}$ Whilst outside the scope of this study, this would have ramifications for policy formulation in strongly multicultural urban areas, and as such lends itself to further research.
} 
negative connotations may apply to eco cars if it was felt those using them were acting in a 'pious' or sanctimonious manner (see anecdotal sources such as Toyotapious [2017]).

\subsection{Data sampling, collection, and analysis}

Bourdieu (1984) has shown that symbolic motivation varies significantly as a function of socio demography within a nation: even within a culture symbols signify different things to different social groups. Accordingly, in cross-cultural analysis sampling is crucial: not only consideration of where to sample but who to sample; random sampling is of little use in cross cultural work as it mixes cultural (horizontal) and social (vertical) motivation (Buil et al., 2012). Hofstede (1984) shows for example how the PDI index for low income groups in low PDI nations, is similar to those exhibited by the more affluent in high PDI nations; the indices only work comparatively at a collective national level. Therefore, what is most likely to yield strong results is stratified purposive sampling, contrasting people who are as similar as possible (Vijver and Leung, 1997). Ohnmacht et al. (2009) term this horizontal sampling.

As to which nations to sample, Hofstede's (1984) indices were used to subdivide nations into two high level contrasting cultural clusters to be compared - high PDI/collectivist and low PDI/individualistic. The four Hofstede (ibid) clusters in this study consisted of:

- Two low PDI/ individualistic cultures:

○ 'Anglo' (Australia, USA, UK, New Zealand, Canada, Ireland)

○ 'Nordic' (Sweden, Norway, Finland, Denmark, the Netherlands ${ }^{3}$

- Two high PDI/collectivist cultures:

○ 'Confucian' (China, Taiwan)

\footnotetext{
${ }^{3}$ Another cultural index that of Inglehart and Oyserman (2004) places the Netherlands within a North European cluster concurring with Sicinski, (1976), that 'Finland, the Netherlands, and Norway' culturally fit closely together.
} 
○ 'South Asian' (India, Pakistan, Bangladesh)

Despite being regional bundles of countries with similar national cultures, the term 'national' culture has, for reasons of continuity with other publications stemming from the research, been maintained. The goal of the research is to assess the symbolism of eco cars in mega cities in India and China to see if there are cultural barriers in place which may hinder their adoption. As this covers two nations, rather than just pick a single low PDI/individualistic cluster with which to contrast them, the authors, sought balance by picking a further - the Nordic. This was an opportunistic decision: some commentators make reference to Nordic and Dutch transport policies offering lessons for the rest of the world, being sufficiently high profile to attract significant attention (Scott, 2014; Pojani and Stead, 2015b). Just as contrasting India and China, however, was not the goal of the paper, neither was contrasting the Anglos with the Nordics. This does afford an opportunity, however, for further analysis within a cluster at a later date. The two major cultural groupings are shown in Figure 1.

The overall sampling criteria are summarized in Table 1 . These inclined the sample towards wealthier, more educated, urbanites. This may be useful for another reason: Chatterjee (2008) has described how in India, environmentalism, if it exists anywhere, is to be found among 'urban elites'. Not mandating that an interviewee's parents needed to have been raised, or currently living in, an urban area does raise the possibility that some interviewees might have been exposed to values other than those predominating in their city. Whilst this is a possible sampling limitation it is assumed that the probability of it occurring would be uniform throughout the clusters, so as not to dilute the overall findings, in relative terms.

Having established the sampling criteria, the primary author then made contact with personal connections in primary cities within the countries being examined. Once the criteria for inclusion had been explained, these personal contacts then suggested interviewees to the primary author, who then made contact via email with those put forward. Following initial 
email discussions, the interviewees, if they fitted the criteria, were selected and a time was arranged. Post their interview, people in turn made further recommendations as to potential participants. Not one of the people approached refused to be interviewed.

\begin{tabular}{|c|c|}
\hline Sampling dimension & Criteria for inclusion \\
\hline $\begin{array}{l}\text { Cross cultural national groups } \\
\text { taken from the Hofstede } \\
\text { (1984) indices: }\end{array}$ & $\begin{array}{l}\text { Two high PDI/collectivist: South Asian (India, Pakistan, Sri } \\
\text { Lanka, Bangladesh) and Confucian (China, Taiwan). Two low } \\
\text { PDI/individualistic: Anglo (UK, USA, Australia, Canada, Ireland, } \\
\text { New Zealand) and Nordic (The Netherlands, Norway, Sweden, } \\
\text { Finland, Iceland, Denmark). }\end{array}$ \\
\hline $\begin{array}{l}\text { Current domicile, urbanity and } \\
\text { mode choice set: }\end{array}$ & $\begin{array}{l}\text { Interviewees must be living in a major urban area with access to a } \\
\text { full modal choice set. A mode should be available even if an } \\
\text { interviewee and/or their family choose not to use it. A full modal } \\
\text { choice set comprises: bus/BRT, metro/tram/commuter rail, non- } \\
\text { motorised options, and car sharing schemes, as well as privately } \\
\text { owned motorised modes - cars, and motorcycles/scooters. 'Eco } \\
\text { cars' such as hybrids and electric vehicles should be available for } \\
\text { purchase. Paratransit is likely in some cities but not mandatory as } \\
\text { sampling criteria. }\end{array}$ \\
\hline Heritage, birth and raising: & $\begin{array}{l}\text { Interviewees needed have been raised in a major urban area in } \\
\text { country, to parents also born and raised in the same nation. }\end{array}$ \\
\hline Education level: & $\begin{array}{l}\text { Interviewees must be educated to degree level. At least one parent } \\
\text { must have a degree. }\end{array}$ \\
\hline Age: & Above eighteen and under fifty years old. \\
\hline Gender: & Equal balance between males and females. \\
\hline Car ownership status: & $\begin{array}{l}\text { The family or individual must have owned a car for at least ten } \\
\text { years. }\end{array}$ \\
\hline Other attributes: & $\begin{array}{l}\text { Interviewees must possess high-speed internet access and speak } \\
\text { fluent English. }\end{array}$ \\
\hline
\end{tabular}

Table 1: Sampling criteria for the interviewees from the population of interest. 


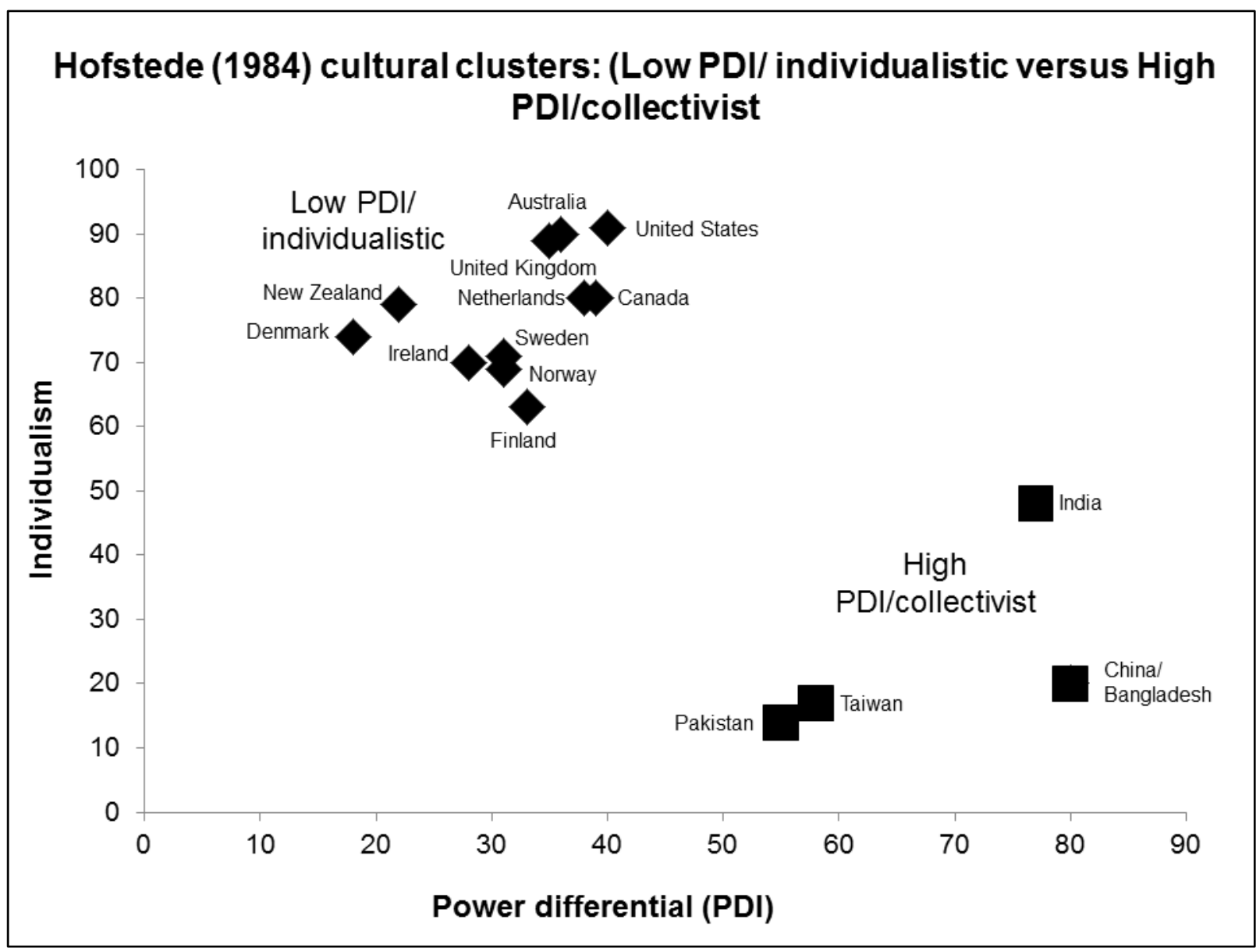

Figure 1: Hofstede (1984) cultural clusters: low PDI/ individualistic versus High $\mathrm{PDI} /$ collectivist

There is also a slight risk that the results may have been affected by the stipulation that the interviews be conducted in English. Symbolism is a complex construct to describe even in a person's first language. If this raises a concern it is that some participants might, for reasons of modesty or linguistic limitation, failed to adequately describe the importance of transport symbolism within their culture. The interviewer did not have the impression that this was the case, and the significant volume of rich data obtained seemingly bear this out, but it must be flagged as a potential limitation.

Convenience sampling was used for initial contacts, and snowball sampling for further recruitment. No firm rules exist on sample size but to achieve saturation of themes there is some agreement among experts that this occurs at around twelve interviewees from each of 
the four groups (Baker and Edwards, 2012; Guest et al., 2006). This made for a total of 48 interviewees, clustered in the following cities: Anglo - London, New York, Sydney, Melbourne; Nordic - Amsterdam, Olso, Rotterdam; Confucian - Beijing, Taipei, Shanghai and Guangzhou, and; South Asian - Chennai, Delhi, Mumbai. A semi-structured approach was deployed exploring themes around the symbolic connotations of various transport modes, including eco cars. One hour long interviews for each participant were conducted in person, via skype, or by telephone, and were recorded and transcribed.

The interviewer knew nothing of the interviewees' prior awareness of eco cars. That said, the entire low PDI/individualist group had heard of, or had had experience of eco cars. This was less the case for the high PDI/collectivist group, with the Confucian culture interviewees having had more exposure to the technology than the South Asians. For participants who needed clarification as to the physical appearance or technical aspects of eco cars, photographs were on hand, supported by verbal descriptions. If the internet connection was poor, or the telephone was used, interviewees were offered the option of having these photographs emailed.

Coding was undertaken manually in accordance with the rules of the codebook in Appendix A. In deductive thematic analysis, thematic validity is established when at least two coders note its presence in a dataset. Interrater coding reliability to establish the credibility of the primary coder was quantified by comparing, for each code, the coding incidence of the primary coder with another coder. For reasons of resource constraints and the high data volumes this was done for the transcripts of the first interviewees from each group. A threshold of over seventy percent was deemed acceptable given that the themes were deduced from theory and were a new area of research. This threshold was achieved for all themes (see Appendix B). This established the credibility of subsequent coding performed by the primary coder. 


\section{$4 \quad$ Findings and discussion}

The findings were guided by thematic coding densities (Table 2) for each cultural cluster of interviewees, and augmented by strong quotes (see Guest et al., 2012; Braun and Clarke, 2006). To support the discussion, colloquialisms were placed in inverted commas (University of Melbourne, 2012)

Table 2 shows significant differences in thematic coding densities per 100,000 transcript words, for positive, neutral, and negative symbolism of eco cars, for the two major cultural groups. Broadly speaking, positive symbolic coding density was far higher for the interviewees from the low PDI/individualistic cultures. Negative symbolism was at least twice as high for the interviewees from the high PDI/collectivist cultures. Neutral symbolism, being symbolically meaningless, was far higher for the interviewees from the high PDI/collectivist cultures.

The goal of the research was not to compare coding scores and densities within the overall high PDI/collectivist and low PDI/collectivist cultures. Furthermore the major contrast shown in Table 2 is between the larger cultural groupings.

\begin{tabular}{|c|c|c|c|c|}
\hline \multirow{2}{*}{ Theme label } & \multicolumn{3}{|c|}{ Frequency counts per code (per 100,000 words) } \\
\cline { 2 - 5 } & \multicolumn{2}{|c|}{ Low PDI/IND } & \multicolumn{2}{c|}{ High PDI/COLL } \\
\cline { 2 - 5 } & Anglo & Nordic & Confucian & South Asian \\
\hline $\begin{array}{l}\text { 1. Eco cars, positive } \\
\text { symbolism }\end{array}$ & 47 & 84 & 5 & 2 \\
\hline $\begin{array}{l}\text { 2. Eco cars, neutral or no } \\
\text { symbolism }\end{array}$ & 2 & 4 & 13 & 22 \\
\hline $\begin{array}{l}\text { 3. Eco cars, negative } \\
\text { symbolism }\end{array}$ & 12 & 12 & 23 & 22 \\
\hline
\end{tabular}

Table 2: Coding densities for eco cars for interviewees for each major cluster and sub cluster. 
The following discussion explores why these differences may be observed for each cluster. Quotes are offered in the format of national cultural group, group interviewee number, city of abode, gender, and age.

\subsection{The symbolism of cars generally across the clusters}

Before discussing the results of the symbolism of eco cars across each cluster, it is first necessary to present the scores for the symbolism of cars generically for each group. This will allow the findings pertaining to eco cars to be contextualised. Table 3 shows the thematic coding density between the groups for the symbolism of cars at a generic level. It may be seen that the interviewees from the high PDI/collectivist cultures saw cars as possessing strong positive symbolism within their cultures. This was not the case for the interviewees from the low PDI nations who largely saw cars as being symbolically irrelevant.

The quotes supported these coding densities:

I mean we're perhaps at the stage here where the car isn't the real indicator...probably a really expensive cycle, show who is really in the middle classes. But not cars (Nordic 11, Amsterdam, F, 28).

\begin{tabular}{|l|c|c|c|c|}
\hline \multirow{2}{*}{ Theme label } & \multicolumn{3}{|c|}{ Frequency counts per code (per 100,000 words) } \\
\cline { 2 - 5 } & \multicolumn{2}{|c|}{ Low PDI/IND } & \multicolumn{2}{c|}{ High PDI/COLL } \\
\cline { 2 - 5 } & Anglo & Nordic & Confucian & South Asian \\
\hline $\begin{array}{l}\text { A. Cars (generic) - } \\
\text { positive symbolism }\end{array}$ & 6 & 16 & 190 & 216 \\
\hline $\begin{array}{l}\text { B. Cars (generic) - neutral } \\
\text { symbolism }\end{array}$ & 45 & 112 & 3 & 0 \\
\hline $\begin{array}{l}\text { C. Cars (generic) - } \\
\text { negative symbolism }\end{array}$ & 20 & 64 & 20 & 2 \\
\hline
\end{tabular}

Table 3: Coding densities for cars generically for high level and sub cultural clusters 
One car? No in that case I think that they would choose the bigger one. Mostly for a symbol. Because in our culture the car isn't only for travelling. You can make a lot of friends if you can drive a good car, and it also helps you with your business (Confucian 12, Beijing, M,25).

\subsection{Eco cars, positive symbolism}

\subsubsection{Interviewees from low PDI/individualistic cultures}

In keeping with the findings of Heffner et al., (2007) and Chua et al. (2010), the interviewees from low PDI/individualistic cultures attached largely positive symbolism to ownership of eco cars. In contrast with their general views on cars in urban areas, the eco car, largely denoting environmental concern, was seen as a visible 'marker' for several connotations including affluence, education, healthy living, and being informed. The following quote summarises this finding:

If a family is driving around in a battery powered car then they'd be environmentally focussed, middle class, gentrified, living in a nice leafy suburb, eating wholefoods (Anglo 1, London, F, 32).

Nobody interviewed from the low PDI/individualistic cultural cluster said that their friends or family would frown upon, or deride their decision to buy an eco car. This did not prevent the low PDI/individualistic interviewees themselves, however, from expressing negative emotions about vehicles such as the Prius (as will be shown in Section 4.3.1).

In contrast to their counterparts from high PDI/collectivist cultures, the interviewees from the low PDI/individualist cultures, stressed that a decision to buy a hybrid would be theirs alone. It might be mentioned to their family and friends, if at all, after the purchase had taken place, but the idea of needing familial approval was seen as extremely strange. This didn't just apply to the purchase of an eco car but a car generally, or any aspect of an adult's transport 
decision. Unlike regular 'prestige' sedans, in the case of a very expensive eco car such as Tesla, the low PDI/individualist group seemed to feel owning one didn't constitute bad taste by overtly flaunting economic capacity, due to the car's environmental credentials. The following quotes illustrate this:

[Family and peers would] like the fact I was showing to people I had a social conscience (Anglo 4, F, Sydney, 32).

My family wouldn't get involved in my mode choice or what I buy. No. (Anglo 2, F, New York City, 28).

My parents are the left leaning liberal types, so they would be really proud of us if we used public transport and bought a Prius (Nordic 10, Rotterdam, F, 33).

Extended family in the decision making process? No. No. It's purely up to us. I wouldn't even talk to them. It's not on the radar. I'm 49, an adult. 'Mummy can I have a car?' (laughs)... I never even did that as a kid. It's my car. I suppose if she expressed disapproval about what I bought I'd argue with her and tell her she was a shallow idiot, but she wouldn't influence the decision one little bit. She'd strengthen my resolve to own the car to annoy her. (Anglo 12, London, M, 49).

The Tesla thing is interesting. That thing has got to be $\$ 100,000$ dollars but it is electric so has a great environmental profile so you're spending a load of money, but you think 'good for you'. My peer group would see this as a good decision and I'm under no illusions about that, and if there is a symbolism around the enviro cars, then that's good (Anglo 11, New York, M, 45).

The interviewees from this group indicated that a modal shift from a regular petrol car, 'prestige branded' or otherwise, would be viewed favorably within their culture. The following quote is typical: 
I think if you sold a BMW or an SUV and went to an eco car then that would generally be well regarded (Nordic 5, Oslo, M, 41).

\subsubsection{Interviewees from high PDI/collectivist cultures}

The interviewees from high PDI/collectivist cultures saw little positive symbolism in owning, or using, an eco car within their culture. Interviewees felt that the eco cars lacked symbolic value as they had not been socially normalised. In an environment where collective decision making predominated, if someone within a family suggested that the family group procure an eco car, it was thought unlikely this would be accepted by the collective; symbolism was stated to be a major factor in this decision. This was true not only for hybrid and electric cars, but for any car purchase.

The only possible group who might constitute an exception in terms of a symbolic aversion to eco cars, was stated to be a small percentage of highly educated young people, schooled in subjects such as planning or environmental science. On a positive note some high PDI/collectivist interviewees stressed that such a clean symbolic 'slate' offered an opportunity to market eco cars to young, 'social trend setters', living away from the interference and constraints of the collective family:

We don't even know the name of the electric vehicle brands. But once they are properly marketed there will be an opportunity. As of now the market is clean for electric vehicles as people have no perceptions... only if I am living alone in Bangalore or some IT hub away from the family then I can buy the vehicle [hybrid car] then tell my father (South Asian 1, Delhi, M, 29).

You see basically every major decision that we make when the extended family are around us has to be done in consultation with them. Every decision that we make we consult with our parents and this applied to [buying] cars too...they do 
have a say. And the relatives in the city, the extended family would also involve themselves in the decisions. (South Asian 12, Delhi/Gurgaon, F, 29).

[When people buy cars]...they have to discuss with their parents....it's a very common thing in China. (Confucian 11, Shanghai, F,28).

The environmental aspect of the hybrid car is not too important to me. In China many people are concerned about the air pollution but this does not affect their decisions when it comes to buying something. (Confucian 2, Taipei, M, 44).

The hybrid car means nothing in our culture. It's just a car. Nobody would buy it to show that they were environmentally concerned. (Confucian 6, Beijing, F, 31).

If the rich people who set the standards choose these cars then people would go for them. At the moment there is no benchmark so it is not seen as the car to be used. Nobody cares (South Asian 2, Chennai, M, 31).

It's only people who work in something like urban planning or transport or creative people that would understand these cars and think that they said something to those around them, something about their education level. It's not a typical type of car choice (South Asian 7, Delhi, F, 31).

In the first tier cities I do not think it will be huge issue for a young couple to choose a hybrid, as many young families are not living with their parents in cities like Shanghai. They move there for work and because their parents are far away, as long as the couple are financially independent then the parents could not be involved too much in the decision. (Confucian 8, Shanghai, F 30). 


\subsection{Eco cars, negative symbolism}

\subsubsection{Interviewees from low PDI/individualistic cultures}

It was noted among the interviewees from low PDI cultures, that some social groups, defined by an extremely positive attitude to the private car, might loathe eco cars for their overt environmental statement. Nobody in the interviewees from the low PDI/individualistic cultures stated these views applied to them personally. This reinforces the need for stratified sampling when exploring symbolic meaning.

People who like cars and driving, they would see the Prius as the Devil's vehicle.

No self-respecting petrol head would touch a Prius (Anglo 12, London, M, 49).

Given the significant positive symbolic connotations of eco cars in low PDI/individualistic cultures, the magnitude of the coding densities for negative connotations might seem surprising. As predicted, however, these instances of coding occurred when the purchaser of an eco car was seen to be behaving in either a stereotyped manner, or worse, flaunting their social class or purchasing capacity, outwardly 'preaching' their 'moral superiority' to others, or being self-righteous, snobbish, hypocritical, or insincere. Negative jibes directed towards these types of eco car owners ranged from playful generalisations to outright indignation and hostility:

Prius: (laughs) ...granola eaters who come from a well off background. They've been to a really liberal school like Brown or UT in Austin. Flowy hair...liberal, vegetarian, a package... does yoga (Anglo 2, F, New York City, 28).

Some comedians hit hard on people who drive the Prius. Mock them (Nordic 1, Rotterdam, M, 48). 
Prius drivers! Pretentious... and the new electric BMWs are very flashy...I'd look down on any person who drove a BMW [regardless of the propulsion method] (Anglo 7, London M, 44).

It's a bit of a fake thing. Everyone knows they [eco cars] aren't that good for the environment (Nordic 4, Oslo, F, 28).

\subsubsection{Interviewees from high PDI/collectivist cultures}

In contrast interviewees from high PDI/collectivist cultures stated that within their societies eco cars overwhelmingly possessed negative or at best neutral symbolism. They described how people purchasing equivalent-sized and branded models had no incentive to spend extra money to 'be seen to be green'. Eco cars were seen as outwardly meaningless, connoting nothing, only bringing symbolic value if the brand was 'Western', not local:

I wouldn't think they were green, trying to do good for the world. I'd think that they were copying people in the West. As long as it is a brand coming from a foreign country then it will be seen as good. But if Tata produce a cheap electric car then the price and the fact that it is local will give the impression that you have downgraded to rubbish (South Asian 2, Chennai, M, 31).

As outwardly expressing concern for the environment was described as having few positive connotations, interviewees from high PDI/collectivist cultures described how eco cars would only be ranked relative to others based on price:

I worked in the government. To show they cared about the environment they bought the directors Prius cars. Some of my friends think this is silly because it does not clearly show the status of the director. They could have bought them bigger cars for the same money to show the status. Environmental cars don't have status (Confucian 2, Taipei, M, 44). 
The problem with eco cars is that people only judge you in India on the price you pay for the car and the model...If your role demands a Mercedes and you show up in a Toyota, people will not think 'hey it's a hybrid!' They won't care. These things are not being played up as important in the adverts (South Asian 9, Delhi, $\mathrm{M}, 48)$.

It was stated that those able to purchase high status, 'prestige' vehicles would see eco cars as 'cheap'. Given this, it was opined that for those who could afford luxury branded cars, there was a significant risk eco cars could symbolise constrained income or misrepresent the collective's true economic capacity relative to others. Some noted that within their culture this could connote frugality or perhaps greed, leading to potentially damaging social consequences: loss of respect or 'face' (termed 'mianzi' in Mandarin - an 'image of self, delineated in terms of approved social attributes' [Goffman, 1955]).

The Prius is kind of low status because it's cheap. People only judge [based] on the price in China. They don't place a focus on the environmental aspect yet (Confucian 12, Beijing, M, 25).

People who do not spend all their disposable income when buying a car in India will be seen as greedy or less talented...My relatives boast about the type of fuel they can afford to buy for their cars. It is related to their social status. If I buy an electric vehicle the people will think I am the worst person, a good for nothing, who is seeking help from others. They will think I bought it to charge it at the office... and show me disrespect for being greedy (South Asian 1, Delhi, M, 29).

It's better to put up with congestion and the horrible air than to be judged the wrong way in society (South Asian 6, Mumbai, M, 32). 
One interviewee from India suggested that public subsidies, offered to encourage the uptake of eco cars, would contribute further to their overt negative symbolism by shaming the owner:

I know the government will give incentives but these send a message to others that you are getting some discount, you have less disposable income, less social status, that you are inferior to the other person (South Asian 1, Delhi, M, 29).

Other interviewees felt that purchasing an eco car could affect one's business prospects or marriageability. Business transactions and arranging marriages were seen as occasions where abiding by conventions, showing financial power and social equivalence, were crucial (see Bloch et al., 2004):

Indians don't like unconventionality. An environmentally friendly choice like a car share or an eco car could hurt your business (South Asian 6, Mumbai, M, 32).

If I was a bystander watching a family who owned a BMW meet another family who drove a Toyota Prius, to discuss the marriage of their kids, I would think 'Okay this is a BMW family meeting a Toyota family. It looks like the BMW family is better off financially'. These things can affect the marriage negotiations (South Asian 10, Mumbai, M, 45).

In terms of modal shift, interviewees noted that switching from a 'high-status' branded car to an eco car would be frowned upon as it could present a sudden fall in economic capacity, and may provoke questions from others in society. Trading in a luxury sedan for an eco car was seen as extremely unlikely, unless the original car was retained to clearly showcase the collective's purchasing power:

If [you] were to change a flashy Audi to a battery car people would think something is wrong, that your salary had dropped (Confucian 12, Beijing, M, 25). 
A rich family owning a BMW would not sell their car to buy a Prius as their only car. They would keep the BMW. The Prius might downgrade the family standard. BMW people are treated differently. If you move to a Prius you go down. People would ask 'why have you done this?' (South Asian 4, Chennai, M, $35)$.

Once again, some members of the high PDI/collectivist interviewees stated that the symbolic prospects for eco cars lay with younger, well-educated people. But, as noted earlier, in an environment of collective decision making and heavy parental involvement in adult children's lives, if the children lived close to the family unit, a risk was noted of their families may prevent them from buying an eco car for fear of status misrepresentation. The issue seemed so contentious that two interviewees from China and India respectively stated that family members could resort to emotional blackmail:

If you traded off your BMW for a hybrid car, which normally costs less, your family might think you need some money as it could signal a financial problem. Aunts might gossip, not because it is a hybrid car but because it is a cheaper car with lower cost. They might think you lost money in the stock market or gambled it away...if a couple told their parents they sold their BMW to get a hybrid to protect the environment the parents would think the reason is fake and you are definitely facing some problems and are too ashamed to tell. Some might try to block your decision...some might get really grumpy about the hybrid car until you give in and accept their 'suggestion'. They'll keep pestering you; sometimes they would pretend they have a headache or stomach ache (Confucian 8, Shanghai, F 30).

My parents will think that I have borrowed money and am in financial trouble if I try and buy an electric vehicle. It will very hard to convince them - they will 
worry people will talk and think their son is an idiot or having problems. They will pressure me not to buy it and if you are living in the home or close to the family, the father has supremacy. If the family and son have an argument over choosing such a vehicle, the father will go to work and call your mother, and your mother will call you, and you won't be able to focus. Your mother will try to talk to your friends, say you are stubborn trying to buy an electric vehicle. They will create an environment where everyone around you is stopping you from going against your father. To get peace of mind you will concede to get rid of the stress (South Asian 1, Delhi, M, 29).

\section{Conclusion: implications for policy transfer and sustainable transport}

The findings demonstrate that for certain groups in low PDI/individualistic societies, products designed to promote greater sustainability will continue to possess strong symbolic value, provided they are demonstrably, visibly, 'different', as in the case of the Toyota Prius. As described by other researchers this symbolism allows adopters of eco cars to outwardly denote caring for the environment, but also connote being a member of a well-educated, caring, progressive, social segment.

The focus of this work, however, is on the symbolic aspects associated with the transfer of sustainable transport policies, in this case the promotion of eco cars, from low PDI/individualistic (generally developed) nations to urbanites in high PDI/collectivist (generally developing) societies. This study indicates that, at this stage in time, other than perhaps for small niche markets such as some highly educated graduates, schooled in disciplines such as urban planning, eco cars possess no symbolism at all. This is in strong contrast to the high symbolic value of cars generally within the high PDI/collectivist cultures. If policy makers in cities such as Delhi and Beijing are serious about promoting eco cars, this will need to be addressed. In these cultures not blending in with the general population 
appears to be highly undesirable so adopting symbols that lack strongly positive symbolic connotations seems to be a subversive exercise in non-conformity. Essentially, there seems to be an imperative for symbols to connote something. If they do not then there seems a significant risk that the adopter of the symbol, and their collective, will be viewed and treated poorly, for breaking the cultural rule of needing to clearly showcase economic capacity and social standing.

This paper also describes a paradox in offering incentives to encourage eco car uptake. It is clear that fiscal incentives for purchasing eco cars, such as tax breaks or exemptions from user charges, have proven successful among relatively affluent market segments in low PDI/individualistic nations. In high PDI/collectivist societies, however, such 'discounts' may connote to others constrained purchasing capacity. Perversely, making eco cars not only clearly discernible from others, but also considerably more expensive than their counterparts, on a par with 'prestige' brands, may encourage their uptake in places such as Delhi, where showing exclusivity, and equivalence, is important in social transactions such as arranging marriages. Having established eco cars as symbolically connoting being a member of the elite, more affordable models could then be promoted.

It should be noted, however, that cultures are ever changing, and in more liberal enclaves, information technology hubs such as Pune or Hyderabad, younger people seem to be embracing individualism, and moving away from the constraints of their collective family dynamics. This may also be the case for younger educated people moving to metropolises such as Shanghai, Beijing and Mumbai, to work, away from their families. Such places may allow tech savvy youth to develop the same environmental concerns as their counterparts in the West, and evolve into an ideal target market for eco cars.

In terms of future research, the strength of the differences in coding density and quotes for the two interviewee cultural clusters is sufficient to justify the expansion of the theory for 
testing among the populations of interest. The next stage of the work would be to convert the findings into attitudinal surveys to measure how the symbolic imperatives and choice dynamics differ between the two high level cultural groups. There is also a reasonable basis for examining symbolic differences within each of the two high level cultural groupings as there are observable differences within each of the high level clusters that may warrant further examination within another study.

Finally, another topic which may be examined at a later date by means of the qualitative dataset obtained in this exercise, will be in-culture socially driven differences in symbolic motivation as alluded to by Bourdieu (1984). Whilst not specifically sought in this work, all of the interviewees commented at length on different social groups in their culture gauged the symbolism of a transport mode, and how this differed from their own cohort. Whilst this examination of the social motivators of symbolism within a culture lies outside the remit of this article - indeed the sampling strategy attempts to negate its effects as much as possible it does offer scope for a significant expansion of the research programme at a later stage. By adding a vertical dimension to the questionnaire, covering income, age, and education levels, the researchers will also be in a position to examine how the symbolic choice imperative works vertically within nations, as well as across them.

\section{Acknowledgements}

The forty eight anonymous interviewees who gave up considerable time to be interviewed deserve great thanks. Whilst they provided volumes of rich data, the responsibility for its interpretation remains solely with the authors. 
Declarations of interest: none. 


\section{References}

Ajanovic, A., Haas, R., 2016. Dissemination of electric vehicles in urban areas: Major factors for success. Energy, Towards low carbon energy systems: engineering and economic perspectives 115, 1451-1458. https://doi.org/10.1016/j.energy.2016.05.040

Anable, J., Skippon, S., Schuitema, G., Kinnear, N., 2011. Who will adopt electric vehicles? A segmentation approach of UK consumers, in: Energy Efficiency First - the Foundations of a Low Carbon Society. Presented at the European Council for an Energy Efficiency Economy, Stockholm, pp. 1015-1026.

Ashmore, D.P., Christie, N., Tyler, N.A., 2017. Symbolic transport choice across national cultures: theoretical considerations for research design. Transportation Planning and Technology.

Ashmore, D.P., Thoreau, R., Kwami, C., Christie, N., Tyler, N.A., In Press. Using thematic analysis to explore symbolism in transport choice across national cultures. Transportation.

Baker, S.E., Edwards, R., 2012. How many qualitative interviews is enough? (Working Paper). NCRM.

Baker, T., Temenos, C., 2015. Urban Policy Mobilities Research: Introduction to a Debate. Int J Urban Regional 39, 824-827. https://doi.org/10.1111/1468-2427.12252

Barthes, R., 1967. Elements of semiology / translated from the French by Annette Lavers and Colin Smith, Cape editions ; no. 4. Cape.

Barthes, R., 1957. Mythologies. Editions du Seuil, Paris.

Belk, R.W., 1988. Possessions and the Extended Self. Journal of Consumer Research 15, 139-168.

Berth, N., 2011. The importance of being seen to be Green: an empirical investigation of Green Marketing Strategies in Business-to-Business organizations (Thesis). Auckland University of Technology.

Bloch, F., Rao, V., Desai, S., 2004. Wedding Celebrations as Conspicuous Consumption: Signaling Social Status in Rural India. Journal of Human Resources 39. https://doi.org/10.2307/3558992

Blumer, H., 1986. Symbolic Interactionism: Perspective and Method. University of California Press.

Bourdieu, P., 1984. Distinction: A Social Critique of the Judgement of Taste. Harvard University Press, Cambridge, Mass.

Boyatzis, R.E., 1998. Transforming qualitative information : thematic analysis and code development / Richard E. Boyatzis. Sage, Thousand Oaks, CA ; London.

Braun, V., Clarke, V., 2006. Using thematic analysis in psychology. Qualitative Research in Psychology 3, 77-101. https://doi.org/10.1191/1478088706qp063oa

Bryman, A., 2012. Social Research Methods. Oxford University Press.

Buil, I., de Chernatony, L., Martínez, E., 2012. Methodological issues in cross-cultural research: An overview and recommendations. Journal of Targeting, Measurement and Analysis for Marketing 20, 223-234. https://doi.org/10.1057/jt.2012.18 
Burnkrant, R.E., Cousineau, A., 1975. Informational and normative social influence in buyer behavior. Journal of Consumer Research 2, 206-215. https://doi.org/10.1086/208633

Chatterjee, D.P., 2008. Oriental disadvantage versus occidental exuberance - Appraising environmental concern in India - A case study in a local context. International Sociology 23, 5-33. https://doi.org/10.1177/0268580907084384

Choi, H., Oh, I., 2010. Analysis of product efficiency of hybrid vehicles and promotion policies. Energy Policy 38, 2262-2271. https://doi.org/10.1016/j.enpol.2009.12.014

Chua, W.Y., Lee, A., Sadeque, S., 2010. Why do people buy hybrid cars? in proceedings of Social Marketing Forum, University of Western Australia, Edith Cowan University, Churchlands, W.A., pp. 1-13.

Clifford, M.L., 2016. Chinese Government Subsidies Play Major Part In Electric Car Maker BYD's Rise [WWW Document]. Forbes. URL https://www.forbes.com/sites/mclifford/2016/07/26/with-a-little-help-from-its-friendslavish-chinese-government-help-for-top-electric-car-maker-byd/ (accessed 10.14.17).

Coolican, H., 2009. Research Methods and Statistics in Psychology. Routledge.

Daniell, K., 2014. The role of national culture in shaping public policy: a review of the literature (H C Coombs Policy Forum). ANU, Canberra.

Dargay, J., Gately, D., Sommer, M., 2007. Vehicle Ownership and Income Growth, Worldwide: 1960-2030. The Energy Journal 28, 143-170.

Denzin, N.K., Lincoln, Y.S. (Eds.), 2005. The SAGE Handbook of Qualitative Research, Third Edition edition. ed. Sage Publications, Inc, Thousand Oaks.

Diamond, D., 2009. The impact of government incentives for hybrid-electric vehicles: Evidence from US states. Energy Policy 37, 972-983. https://doi.org/10.1016/j.enpol.2008.09.094

Dittmar, H., 1992. The social psychology of material possessions: to have is to be. Harvester Wheatsheaf.

Fereday, J., Muir-Cochrane, E., 2008. Demonstrating Rigor Using Thematic Analysis: A Hybrid Approach of Inductive and Deductive Coding and Theme Development. International Journal of Qualitative Methods 5, 80-92.

Festinger, L., 1954. A Theory of Social Comparison Processes. Human Relations 7, 117-140. https://doi.org/10.1177/001872675400700202

Gartman, D., 2004. Three Ages of the Automobile: The Cultural Logics of The Car. Theory, Culture \& Society 21, 169-195. https://doi.org/10.1177/0263276404046066

González, S., 2011. Bilbao and Barcelona 'in Motion'. How Urban Regeneration 'Models' Travel and Mutate in the Global Flows of Policy Tourism. Urban Studies 48, 13971418. https://doi.org/10.1177/0042098010374510

Guest, G., Bunce, A., Johnson, L., 2006. How many interviews are enough? An experiment with data saturation and variability. Field Methods 18, 59-82. https://doi.org/10.1177/1525822X05279903

Guest, G., MacQueen, K., Namey, E., 2012. Applied Thematic Analysis. Sage Publications, Inc, Los Angeles. 
Hao, H., Ou, X., Du, J., Wang, H., Ouyang, M., 2014. China's electric vehicle subsidy scheme: Rationale and impacts. Energy Policy 73, 722-732. https://doi.org/10.1016/j.enpol.2014.05.022

Harris, P.G., 2006. Environmental Perspectives and Behavior in China Synopsis and Bibliography. Environment and Behavior 38, 5-21. https://doi.org/10.1177/0013916505280087

Healey, P., 2010. Introduction: The transnational flow of knowledge and expertise in the planning field. Crossing Borders: International Exchange and Planning Practices 1-25.

Heffner, R.R., Kurani, K.S., Turrentine, T.S., 2007. Symbolism in California's early market for hybrid electric vehicles. Transportation Research Part D -Transport and Environment 12. https://doi.org/10.1016/j.trd.2007.04.003

Helveston, J.P., Liu, Y., Feit, E.M., Fuchs, E., Klampfl, E., Michalek, J.J., 2015. Will subsidies drive electric vehicle adoption? Measuring consumer preferences in the U.S. and China. Transportation Research Part A: Policy and Practice 73, 96-112. https://doi.org/10.1016/j.tra.2015.01.002

Hjelmslev, L., 1953. Prolegomena to a Theory of Language, Revised edition edition. ed. University of Wisconsin Press, Madison, Wisc.

Ho, C., Mulley, C., 2015. Intra-household interactions in transport research: a review. Transport Reviews 35, 33-55. https://doi.org/10.1080/01441647.2014.993745

Hofstede, G., 1984. Culture's Consequences: International Differences in Work-Related Values. Sage.

Hofstede, G., Hofstede, G.J., Minkov, M., 2010. Cultures and Organizations: Software of the Mind, Third Edition. McGraw Hill Professional.

Indian Express, 2014. Boost for electric and hybrid cars with Rs 1.5 Lakh subsidy | The Indian Express.

Inglehart, R., Baker, W.E., 2000. Modernization, Cultural Change, and the Persistence of Traditional Values. American Sociological Review 65, 19-51. https://doi.org/10.2307/2657288

Inglehart, R., Oyserman, D., 2004. Individualism, autonomy and self expression: the human development syndrome, in: Vinken, H., Soeters, J., Ester, P. (Eds.), Comparing Cultures, Dimensions of Culture in a Comparative Perspective. Brill.

Jones, M., 2007. Hofstede - Culturally questionable? Paper presented to the Oxford Business \& Economics Conference, Oxford, UK, 24-26 June.

Karasz, A., Singelis, T.M., 2009. Qualitative and Mixed Methods Research in Cross-Cultural Psychology. Journal of Cross-Cultural Psychology 40, 909-916. https://doi.org/10.1177/0022022109349172

Kim, Y.K., Lee, H.R., 2009. Airline employee's service behavior toward different nationalities. International Journal of Hospitality Management 28, 454-465. https://doi.org/10.1016/j.ijhm.2009.01.007

Koçak, A., Abimbola, T., Özer, A., 2007. Consumer Brand Equity in a Cross-cultural Replication: An Evaluation of a Scale. Journal of Marketing Management 23. https://doi.org/10.1362/026725707X178611 
Kroeber, A.L., Kluckhohn, C., 1952. Culture: a critical review of concepts and definitions. Papers. Peabody Museum of Archaeology \& Ethnology, Harvard University 47, viii, 223.

Kuhnimhof, T., Wulfhorst, G., 2013. The Reader's Guide to Mobility Culture, in: Megacity Mobility Culture, Lecture Notes in Mobility. Springer Berlin Heidelberg, pp. 55-64.

Langbroek, J.H.M., Franklin, J.P., Susilo, Y.O., 2016. The effect of policy incentives on electric vehicle adoption. Energy Policy 94, 94-103.

https://doi.org/10.1016/j.enpol.2016.03.050

Lave, L.B., Maclean, H.L., 2001. Are hybrid vehicles worth it? IEEE Spectrum 38, 47-50. https://doi.org/10.1109/6.908852

Law, S.F., Karnilowicz, W., 2015. 'In Our Country it's Just Poor People who Ride a Bike': Place, Displacement and Cycling in Australia. J. Community Appl. Soc. Psychol. 25, 296-309. https://doi.org/10.1002/casp.2215

Lee, Y.M., Sheppard, E., Crundall, D., 2015. Cross-cultural effects on the perception and appraisal of approaching motorcycles at junctions. Transportation Research Part F: Psychology and Behaviour 31, 77-86. https://doi.org/10.1016/j.trf.2015.03.013

Lévay, P.Z., Drossinos, Y., Thiel, C., 2017. The effect of fiscal incentives on market penetration of electric vehicles: A pairwise comparison of total cost of ownership. Energy Policy 105, 524-533. https://doi.org/10.1016/j.enpol.2017.02.054

Lindemann, K., 2007. The impact of objective characteristics on subjective social position. Trames $154-68$.

Magnusson, P., Wilson, R.T., Zdravkovic, S., Zhou, J.X., Westjohn, S.A., 2008. Breaking through the cultural clutter - A comparative assessment of multiple cultural and institutional frameworks. International Marketing Review 25. https://doi.org/10.1108/02651330810866272

Malhotra, N.K., McCort, J.D., 2001. A cross-cultural comparison of behavioral intention models - Theoretical consideration and an empirical investigation. International Marketing Review 18, 235-269. https://doi.org/10.1108/02651330110396505

Markus, H.R., Kitayama, S., 1991. Culture and the self: Implications for cognition, emotion, and motivation. Psychological Review 98, 224-253. https://doi.org/10.1037/0033295X.98.2.224

Marsden, G., Stead, D., 2011. Policy transfer and learning in the field of transport: A review of concepts and evidence. Transport Policy 18, 492-500. https://doi.org/10.1016/j.tranpol.2010.10.007

Matsumoto, D., Juang, L., 2012. Culture and Psychology, 5th Edition, 5th edition. ed. Wadsworth Publishing, Belmont, CA.

Mersky, A.C., Sprei, F., Samaras, C., Qian, Z. (Sean), 2016. Effectiveness of incentives on electric vehicle adoption in Norway. Transportation Research Part D: Transport and Environment 46, 56-68. https://doi.org/10.1016/j.trd.2016.03.011

Miller, D., 2001. Car cultures / edited by Daniel Miller. Berg, Oxford.

Miller, W.L., Crabtree, B.F., 1992. Primary care research: A multimethod typology and qualitative road map, in: Crabtree, B. F., Miller, W. L. (Eds.), Doing Qualitative Research, Research Methods for Primary Care, Vol. 3. Sage Publications, Inc, Thousand Oaks, CA, US, pp. 3-28. 
Minkov, M., Hofstede, G., 2011. The evolution of Hofstede's doctrine. Cross Cultural Management - an international journal 18. https://doi.org/10.1108/13527601111104269

Mulholland, J., 1991. The Language of Negotiation: A Handbook of Practical Strategies for Improving Communication. Routledge.

Ng, S.I., Lee, J.A., Soutar, G.N., 2007. Are Hofstede's and Schwartz's value frameworks congruent? International Marketing Review 24. https://doi.org/10.1108/02651330710741802

Ni, J., 2008. Motorization, Vehicle Purchase and Use Behavior in China: A Shanghai Survey $(\mathrm{PhD})$. University of California Davies.

Noppers, E.H., Keizer, K., Bolderdijk, J.W., Steg, L., 2014. The adoption of sustainable innovations: Driven by symbolic and environmental motives. Global Environmental Change 25, 52-62. https://doi.org/10.1016/j.gloenvcha.2014.01.012

Ohnmacht, T., Maksim, H., Bergman, M.M., 2009. Mobilities and inequality / edited by Timo Ohnmacht, Hanja Maksim, Manfred Max Bergman., Transport and society. Ashgate, Farnham.

Oliver, J.D., Lee, S., 2010. Hybrid car purchase intentions: a cross-cultural analysis. Journal of Consumer Marketing 27, 96-103. https://doi.org/10.1108/07363761011027204

Pojani, D., Stead, D., 2015a. Sustainable Urban Transport in the Developing World: Beyond Megacities. Sustainability 7, 7784-7805. https://doi.org/10.3390/su7067784

Pojani, D., Stead, D., 2015b. Going Dutch? The export of sustainable land-use and transport planning concepts from the Netherlands. Urban Studies 52, 1558-1576. https://doi.org/10.1177/0042098014562326

PTI, 2017. India eyes all-electric car fleet by 2030, says Piyush Goyal [WWW Document]. http://www.livemint.com/. URL http://www.livemint.com/Industry/JvyUPmrumUS832KL5BKzhN/India-eyesallelectric-car-fleet-by-2030-says-Piyush-Goyal.html (accessed 9.14.17).

Rapaille, C., 2001. 7 Secrets of Marketing in a Multi-Cultural World, 1 edition. ed. Executive Excellence Publishing, Provo, Utah.

Sasaki, I., Yoshikawa, K., 2014. Going beyond national cultures - Dynamic interaction between intra-national, regional, and organizational realities. Journal of World Business 49, 455-464. https://doi.org/10.1016/j.jwb.2013.10.005

Saussure, F. de, Bally, C., Riedlinger, A., Baskin, W., Culler, J.D., Sechehaye, A., 1916. Course in general linguistics. Owen, London.

Savani, K., Morris, M.W., Naidu, N.V.R., 2012. Deference in Indians' decision making: introjected goals or injunctive norms? J Pers Soc Psychol 102, 685-699. https://doi.org/10.1037/a0026415

Scott, A., 2014. Northern Lights: The Positive Policy Example of Sweden, Finland, Denmark and Norway. Monash University Publishing, Clayton, Victoria, Australia.

Shavitt, S., Toreli, C., Riemer, H., 2010. Horizontal and Vertical Individualism and Collectivism - Implications for Understanding Psychological Processes, in: 'Advances in Culture and Psychology: Volume 1, Gelfand, M., Chiu,Chi-Yue., Ying-Yi Hong (Eds). Oxford Scholarship Online. 
Sicinski, A., 1976. The future a dimension is being discovered, in: Images of the World in the Year 2000: A Comparative Ten Nation Study. Humanities Press, Atlantic Highlands, pp. 121-159.

Siddique, S., Ray, M., Lahiri, T., 2011. Effects of air pollution on the respiratory health of children: a study in the capital city of India. Air Quality, Atmosphere \& Health 4. https://doi.org/10.1007/s11869-010-0079-2

Sierzchula, W., Bakker, S., Maat, K., van Wee, B., 2014. The influence of financial incentives and other socio-economic factors on electric vehicle adoption. Energy Policy 68, 183-194. https://doi.org/10.1016/j.enpol.2014.01.043

Silvia, C., Krause, R.M., 2016. Assessing the impact of policy interventions on the adoption of plug-in electric vehicles: An agent-based model. Energy Policy 96, 105-118. https://doi.org/10.1016/j.enpol.2016.05.039

Stead, D., Pojani, D., 2017. The Urban Transport Crisis in Emerging Economies: A Comparative Overview, in: The Urban Transport Crisis in Emerging Economies, The Urban Book Series. Springer, Cham, pp. 283-295. https://doi.org/10.1007/978-3-31943851-1_14

Steenkamp, J.E.M., 2001. The role of national culture in international marketing research. International Marketing Review 18, 30-44. https://doi.org/10.1108/02651330110381970

Steg, L., 2005. Car use: lust and must. Instrumental, symbolic and affective motives for car use. Transportation Research Part A Policy and Practice 39. https://doi.org/10.1016/j.tra.2004.07.001

Steg, L., Vlek, C., Slotegraaf, G., 2001. Instrumental-reasoned and symbolic-affective motives for using a motor car. Transportation Research Part F: Traffic Psychology and Behaviour 4, 151-169. https://doi.org/10.1016/S1369-8478(01)00020-1

Strohschneider, S., 2002. Cultural factors in complex decision making, in: Online Readings in Psychology and Culture, W. J. Lonner, D. L. Dinnel, S. A. Hayes, \& D. N. Sattler (Eds.), (Unit 4, Chapter 1), Center for Cross-Cultural Research, Western Washington University, Bellingham, Washington USA.

Swaidan, Z., 2012. Culture and Consumer Ethics. J Bus Ethics 108, 201-213. https://doi.org/10.1007/s10551-011-1070-Z

Syam, A., 2014. Cultural values: a new approach to explain people's travel behaviour and attitudes toward transport mode (Thesis). University of Auckland, https://researchspace.auckland.ac.nz/handle/2292/23559.

Syam, A., Reeves, D., Khan, A., 2011. The effects of cultural dimension on people's perception about security on public transport. In A. Pratelli, C. A. Brebbia (Eds.) Urban Transport XVII: Urban Transport and the Environment in the 21st Century, 575-586. Southhampton, UK: WIT Press.

Takahashi, M., 2010. Talking to the driver: a cross-cultural comparison of bus etiquette in Canada and Japan. Journal of Bunkyo Gakuin University, Department of Foreign Languages and Bunkyo Gakuin College 169-182.

Tansey, R., Hyman, M.R., Zinkhan, G.M., 1990. Cultural Themes in Brazilian and U.S. Auto Ads: A Cross-Cultural Comparison. Journal of Advertising 19, 30-39. 
Taras, V., Steel, P., Kirkman, B.L., 2012. Improving national cultural indices using a longitudinal meta-analysis of Hofstede's dimensions. Journal of World Business 47, 329-341. https://doi.org/10.1016/j.jwb.2011.05.001

The New York Times, 2017. Opinion | China and India Make Big Strides on Climate Change. The New York Times.

The World Bank, 2015. Should we continue to use the term "developing world"? The Data Blog.

Toyotapious, 2017. Toyota Pious [WWW Document]. URL http://toyotapious.com/ (accessed 10.25.17).

Turrentine, T.S., Kurani, K.S., 2007. Car buyers and fuel economy? Energy Policy 35, $1213-$ 1223. https://doi.org/10.1016/j.enpol.2006.03.005

University of Melbourne, 2012. Using quotation marks in writing.

Vaismoradi, M., Turunen, H., Bondas, T., 2013. Content analysis and thematic analysis: Implications for conducting a qualitative descriptive study. Nurs Health Sci 15, 398405. https://doi.org/10.1111/nhs.12048

Vijver, F.J.R. van de, Leung, K., 1997. Methods and Data Analysis for Cross-Cultural Research. SAGE Publications.

Wang, R., 2010. Shaping urban transport policies in China: Will copying foreign policies work? Transport Policy 17, 147-152. https://doi.org/10.1016/j.tranpol.2010.01.001

Williamson, D., 2002. Forward from a Critique of Hofstede's Model of National Culture. Human Relations 55, 1373-1395. https://doi.org/10.1177/00187267025511006

Wind, S., Jensen, O.B., Kaplan, S., Prato, C.G., 2012. Paving the road from transport models to "new mobilities" models. Trafikdage Proceedings from the Annual Transport Conference at Aalborg University 2012.

Witchalls, P.J., 2012. Is national culture still relevant? Interculture Journal 11.

Yabe, K., Shinoda, Y., Seki, T., Tanaka, H., Akisawa, A., 2012. Market penetration speed and effects on $\mathrm{CO} 2$ reduction of electric vehicles and plug-in hybrid electric vehicles in Japan. Energy Policy 45, 529-540. https://doi.org/10.1016/j.enpol.2012.02.068

Zaltman, G., Coulter, R., 1995. Seeing the voice of the customer - metaphor based advertising research. Journal of advertising research 35, 35-51.

Zhang, Y., Neelankavil, J.P., 1997. The influence of culture on advertising effectiveness in China and the USA: A cross-cultural study. European Journal of Marketing 31, 134 149. https://doi.org/10.1108/03090569710157106

Zhou, Y., Wu, Y., Yang, L., Fu, L., He, K., Wang, S., Hao, J., Chen, J., Li, C., 2010. The impact of transportation control measures on emission reductions during the 2008 Olympic Games in Beijing, China. Atmospheric Environment 44, 285-293. https://doi.org/10.1016/j.atmosenv.2009.10.040 


\section{Appendix A: Thematic codebook for individual modes}

\begin{tabular}{|c|c|}
\hline Theme 1 & Mode positive symbolism. \\
\hline $\begin{array}{l}\text { A definition of what } \\
\text { the theme concerns }\end{array}$ & Mode connotes positive symbolism within a culture. \\
\hline $\begin{array}{l}\text { A description of how to } \\
\text { see when the theme is } \\
\text { occurring (how to flag } \\
\text { it) }\end{array}$ & $\begin{array}{l}\text { When interviewees from a particular culture flag that, for } \\
\text { someone of their social group, a mode would be seen as } \\
\text { appropriate, viewed well by their peers, worthy of their cohort, } \\
\text { correctly showcasing the group to which they belong. When it is } \\
\text { stressed that people would wish to use this mode for the reason it } \\
\text { shows them, and their 'in group', in a positive light, presents them } \\
\text { correctly. When using the mode in question would lead to society } \\
\text { understanding who the user and their group, 'are'. When friends, } \\
\text { families, colleagues, peers, would encourage someone to use this } \\
\text { mode due to the image it presents. When it is stressed that using } \\
\text { this mode would lead to positive consequences in terms of } \\
\text { treatment from society. When it is stated that generally using this } \\
\text { mode would be 'seen well'. }\end{array}$ \\
\hline $\begin{array}{l}\text { A description of when } \\
\text { the code should not be } \\
\text { used }\end{array}$ & $\begin{array}{l}\text { When positive practical reasons are stressed. The positivity } \\
\text { should only apply to the symbolic connotations. }\end{array}$ \\
\hline $\begin{array}{l}\text { Examples both positive } \\
\text { and negative to } \\
\text { eliminate confusion }\end{array}$ & $\begin{array}{l}\text { Positive (code): } \\
\text { 'This mode of transport is seen favourably by those in my culture, } \\
\text { definitely in my group. People would applaud you for using it - it } \\
\text { would say good things about you.' } \\
\text { 'Your parents would love you using this mode as it would } \\
\text { demonstrate something positive about the family.' } \\
\text { 'Yes, this mode shows people care about the environment, have a } \\
\text { degree of education and involvement in the debate.' } \\
\text { Negative (don't code): } \\
\text { 'It's a great way to get around. You can stay dry.' (Practical) }\end{array}$ \\
\hline
\end{tabular}




\begin{tabular}{|c|c|}
\hline Theme 2 & Mode neutral or no symbolism. \\
\hline $\begin{array}{l}\text { A definition of what } \\
\text { the theme concerns }\end{array}$ & Mode connotes nothing within a culture. \\
\hline $\begin{array}{l}\text { A description of how to } \\
\text { see when the theme is } \\
\text { occurring (how to flag } \\
\text { it) }\end{array}$ & $\begin{array}{l}\text { When people express that the ownership or use of the mode has } \\
\text { no symbolism, either positive or negative. When it is said that } \\
\text { normative influences such as advertising or friends never mention } \\
\text { the mode as a social marker. When people state that nobody } \\
\text { would care or form a judgement about someone who used this } \\
\text { mode. When there are no reference points by which to judge the } \\
\text { mode symbolically. Code this even if the ramification is neutral } \\
\text { or negative. }\end{array}$ \\
\hline $\begin{array}{l}\text { A description of when } \\
\text { the code should not be } \\
\text { used }\end{array}$ & $\begin{array}{l}\text { When practical reasons are stressed for the indifference. The } \\
\text { neutrality should only apply to the symbolic connotations. }\end{array}$ \\
\hline $\begin{array}{l}\text { Examples both positive } \\
\text { and negative to } \\
\text { eliminate confusion }\end{array}$ & $\begin{array}{l}\text { Positive (code): } \\
\text { 'People don't care - it doesn't say anything.' } \\
\text { 'Ah, if you were to tell me that the person could still afford an } \\
\text { expensive petrol car, but chose to buy this because they cared } \\
\text { about the environment, then I would think differently. But I know } \\
\text { nothing of these things.' } \\
\text { 'The fact that it says nothing would mean that your client would } \\
\text { be confused about the success of the person they were hiring'. } \\
\text { (Neutral symbolism with negative ramifications). } \\
\text { 'Who cares if people travel by bus?' } \\
\text { Negative (don't code): } \\
\text { 'To be honest the bus and the train take about the same time, so } \\
\text { you could use either'. (Practical not symbolic). }\end{array}$ \\
\hline
\end{tabular}




\begin{tabular}{|c|c|}
\hline Theme 3 & Mode negative symbolism. \\
\hline $\begin{array}{l}\text { A definition of what the } \\
\text { theme concerns }\end{array}$ & Mode connotes negative symbolism within a culture. \\
\hline $\begin{array}{l}\text { A description of how to } \\
\text { see when the theme is } \\
\text { occurring (how to flag it) }\end{array}$ & $\begin{array}{l}\text { When people state that the mode portrays the owner or user in a } \\
\text { negative light. When interviewees flag that, for someone of } \\
\text { their social group, a mode would be seen as inappropriate, } \\
\text { viewed poorly by their peers, be viewed as beneath their cohort. } \\
\text { When it is stressed that people would not wish to use this mode } \\
\text { purely for the reason that it showcases them and their 'in group', } \\
\text { in a poor light, presents them incorrectly in a social context. } \\
\text { When using the mode in question would lead to society } \\
\text { misinterpreting who the user and their group, 'are', and treating } \\
\text { them inappropriately. When friends, families, colleagues, peers, } \\
\text { would discourage, prevent, someone from using this mode, due } \\
\text { to its image. When it is stressed using this mode would lead to } \\
\text { negative consequences in terms of treatment from society. } \\
\text { When derision is expressed towards those using this mode. }\end{array}$ \\
\hline $\begin{array}{l}\text { A description of when } \\
\text { the code should not be } \\
\text { used }\end{array}$ & $\begin{array}{l}\text { When negative practical reasons are stressed. The negativity } \\
\text { should only apply to the symbolic connotations. In addition, } \\
\text { when there is a neutral connotation having a negative } \\
\text { ramification (this should be coded under neutral symbolism). }\end{array}$ \\
\hline $\begin{array}{l}\text { Examples both positive } \\
\text { and negative to eliminate } \\
\text { confusion }\end{array}$ & $\begin{array}{l}\text { Positive (code): } \\
\text { 'In my culture this mode of transport would show your family in } \\
\text { a poor light. They would discourage you from using it, as it } \\
\text { would not play well for the family in social dealings'. } \\
\text { 'This is a mode for lower class people.' } \\
\text { 'Oh no, this is a showy mode. In our culture you are supposed } \\
\text { to be discreet about displaying your wealth or status.' } \\
\text { Negative (don't code): } \\
\text { 'This is a bad mode - it takes a long time to get to your } \\
\text { destination.' (Practical not symbolic). } \\
\text { 'It means nothing. People wouldn't treat you well.' (Neutral } \\
\text { connotation with negative ramifications). }\end{array}$ \\
\hline
\end{tabular}




\section{Appendix B - Interrater reliability coding scores}

\begin{tabular}{|c|c|c|c|c|}
\hline \multirow{2}{*}{ Theme 1} & \multicolumn{4}{|c|}{ Eco cars - positive symbolism } \\
\hline & Anglo 1 & Nordic 1 & Confucian 1 & South Asian 1 \\
\hline $\begin{array}{l}\text { Number of times both saw } \\
\text { the code present }\end{array}$ & 1 & 1 & 0 & 0 \\
\hline $\begin{array}{l}\text { Number of times primary } \\
\text { coder saw it }\end{array}$ & 1 & 1 & 0 & 0 \\
\hline $\begin{array}{l}\text { Number of times secondary } \\
\text { coder saw it }\end{array}$ & 1 & 1 & 0 & 0 \\
\hline $\begin{array}{l}\text { Percentage agreement on } \\
\text { presence }\end{array}$ & $100 \%$ & $100 \%$ & $100 \%$ & $100 \%$ \\
\hline \multirow{2}{*}{ Theme 2} & \multicolumn{4}{|c|}{ Eco cars - negative symbolism } \\
\hline & Anglo 1 & Nordic 1 & Confucian 1 & South Asian 1 \\
\hline $\begin{array}{l}\text { Number of times both saw } \\
\text { the code present }\end{array}$ & 10 & 6 & 7 & 1 \\
\hline $\begin{array}{l}\text { Number of times primary } \\
\text { coder saw it }\end{array}$ & 10 & 7 & 8 & 1 \\
\hline $\begin{array}{l}\text { Number of times secondary } \\
\text { coder saw it }\end{array}$ & 10 & 6 & 8 & 1 \\
\hline $\begin{array}{l}\text { Percentage agreement on } \\
\text { presence }\end{array}$ & $100 \%$ & $92 \%$ & $88 \%$ & $100 \%$ \\
\hline \multirow{2}{*}{ Theme 3} & \multicolumn{4}{|c|}{ Eco cars - negative symbolism } \\
\hline & Anglo 1 & Nordic 1 & Confucian 1 & South Asian 1 \\
\hline $\begin{array}{l}\text { Number of times both saw } \\
\text { the code present }\end{array}$ & 2 & 0 & 1 & 1 \\
\hline $\begin{array}{l}\text { Number of times primary } \\
\text { coder saw it }\end{array}$ & 3 & 0 & 1 & 1 \\
\hline $\begin{array}{l}\text { Number of times secondary } \\
\text { coder saw it }\end{array}$ & 2 & 0 & 1 & 1 \\
\hline $\begin{array}{l}\text { Percentage agreement on } \\
\text { presence }\end{array}$ & $80 \%$ & $100 \%$ & $100 \%$ & $100 \%$ \\
\hline
\end{tabular}

